\title{
Strategy for Empowering the City of Surabaya as a Disability-Friendly and Elderly Friendly City
}

\author{
Mochamad Purnomo ${ }^{1, *}$, Sapto Wibowo ${ }^{2}$, Kunjung Ashadi ${ }^{3}$, Hijrin Fithroni $^{4}$ \\ ${ }^{1,2,3,4}$ Faculty of Sport Science, State University of Surabaya, Surabaya, \\ *Email: mochamadpurnomo@unesa.ac.id
}

\begin{abstract}
As citizens, persons with disabilities and the elderly have the same rights to live independently. This right can only be fulfilled if public facilities that support their accessibility are well available. Realizing this need, the Surabaya City government then launched a program to make Surabaya a disability and elderly friendly city. The approach in this study uses a qualitative approach by conducting observations, in-depth interviews and literature studies. One of the most significant strategies is to build public facilities that are disability and elderly friendly. However, empirical findings in the field show that public facilities are not yet fully accessible to persons with disabilities and the elderly. Facilities intended for persons with disabilities and the elderly do not provide optimal benefits because they are not in accordance with internationally accepted universal designs. There are several challenges that must be faced in realizing Surabaya as a friendly city for people with disabilities and the elderly. The bureaucracy and society lack awareness of disability and the equal rights of persons with disabilities. Coordination between parties involved in the construction of public facilities is not yet optimal, so there are many facilities that are planned to be disability friendly and in practice this is not the case. The replacement of regional heads and political dynamics also allows the slow formation of regulations at the regional level related to public services that are sensitive to the needs of people with disabilities and the elderly. In the midst of these challenges, it is still possible to make Surabaya a disability-friendly city by choosing the right strategy. This research produces strategies that can be used in realizing Surabaya as a friendly city for people with disabilities and the elderly.
\end{abstract}

Keywords: Services, Accessibility, Disability, Elderly.

\section{INTRODUCTION}

Public facilities and services are one of four aspects that must exist in realizing accessibility for persons with disabilities. The facilities themselves are classified as the backbone in realizing good public services. What is meant by public service here includes the provision of public services, public affairs (public interests and needs) and the provision of fair and nondiscriminatory public services" [1]. The concept of public service, known as the New Public Service (NPS), places service recipients as citizens, an idea that has slow roots, disconnects and suddenly leaves the virtual classroom. Suddenly there is a study assistant that can be watched carefully. On the concept of the welfare state [2] Public services need to be provided in a fair and non-discriminatory manner [3], including to persons with disabilities. As citizens with rights protected by the constitution, persons with disabilities have the right to get excellent service in various fields of life. It is the responsibility of the government to provide services that can be enjoyed by everyone. In fact, almost every individual will experience a disability in his life, namely when an individual is already at an advanced stage [4]. For that, related to disability, public facilities must be able to be used by persons with disabilities
In terms of accessibility, the study can be divided into two main focuses, namely: the place and capabilities of persons with disabilities. An analysis of the place is related to whether public facilities and services have accommodated the interests and needs of persons with disabilities, while an analysis of the capabilities of persons with disabilities is related to whether individuals with disabilities are able to use the available facilities and services. For this reason, the concept of accessibility speaks of a measure of comfort or ease of achieving a location and its relationship to one another, whether it is easy or difficult for the location to be reached through transportation [5]

To see the high or low accessibility can be seen from the number of network systems available in the area. The more network systems available in the area, the easier the accessibility obtained and vice versa, the lower the level of accessibility obtained, the more difficult it is to reach the area from other areas [6]

As for the criteria for measuring the ideal accessibility, it can be seen from 4 (four) aspects, namely security, convenience, comfort and aesthetics [5]. For this reason, this study will also explain how these criteria can meet persons with disabilities. 
Statistical data shows the number of people with disabilities in Indonesia has increased every year. According to PUSDATIN data from the Ministry of Social [3], in 2010, the number of people with disabilities in Indonesia reached 11,580,117 people, including 3,474,035 (visual disability), 3,010,830 (physical disability), 2,547,626 (hearing disability), 1,389,614 mental disability) and 1,158,012 (chronic disability). Meanwhile, according to data from the Ministry of Manpower and Transmigration, in 2010 the number of persons with disabilities was: 7,126,409 people. This figure does look small compared to the total population of Indonesia, which is around 261.9 million people [7]. However, public services must be fair to every citizen.

In recent years, the City of Surabaya is intensively building physical facilities related to the development of its urban planning, starting from the construction of sidewalks, special bicycle roads, parks, and other public facilities. The reality on the ground shows that the accessibility of the city of Surabaya does not meet the universal design standards and the specified accessibility measurement criteria so that many do not function optimally for people with disabilities and the elderly. In this study the authors focus on the accessibility of public services in the city of Surabaya.

When looking at research on public services for the fulfillment of disability rights in the City of Yogyakarta [8], the strategy carried out by the City of Yogyakarta emphasizes proper education for people with disabilities with the existence of an SLB curriculum that is in accordance with standards, plus the creation of a Blind Corner in the city of Yogyakarta. Regional Libraries are also rehabilitation programs and social services. In addition to educational support, there is also support in the field of transportation such as Transjogja, Giwangan Terminal which can be accessed by people with disabilities. Talking about this research becomes a reference inresearch in the city of Surabaya, where the city of Surabaya does it more comprehensively in terms of physical accessibilityby supporting the city not only through transportation but public buildings and public spaces become a priority.

This activity will have a direct impact on Surabaya residents with disabilities and the elderly in terms of ease of access to public services, besides that people with disabilities and the elderly get convenience in all things. Likewise, Surabaya City Government partners are also helped in increasing their role in services for people with disabilities andthe elderly.

This activity will be funded by the Ministry of Education and Culture through the Maching Fun program by sharing funding from the Surabaya City Government, both in-cash and in-kind, in the form of socialization and construction of public facilities that are disability-friendly and elderly in Surabaya. The urgency of this research is to (1) find out how to further strategies to make the city of Surabaya as a friendly city for people with disabilities in the perspective of accessibility of public services (2) find out how to further strategies to make the city of Surabaya as an elderly friendly city in the perspective of accessibility of public services.

\section{METHODS}

This research design uses a qualitative approach. A qualitative approach is used to reveal comprehensively, in depth and what it is how the realization of the City of Surabayaas a friendly city for people with disabilities and the elderly seen from the perspective of accessibility of public services.

This research is located in the city of Surabaya. This location was chosen based on the third largest elderly population in East Java.

Population is the overall value of the results of calculations or quantitative and quality measurements related to certain characteristics of all members of a complete and clear group to study its nature [9]. The population of this study was the entire population of the elderly and disabled in Surabaya.

According to [10], the sample is a part of the whole and the characteristics possessed by a population. The determination of informants was carried out using purposive sampling, namely informants who were considered to have knowledge or information related to the realization of the City of Surabaya as a Disability and Elderly Friendly City consisting of the Social Service, Transportation Service, Public Works Service, Community of Persons with Disabilities and Observing Organizations for Persons with Disabilities in this case are Bandung Independent Living Center (BILIC)

Literature study, data collection techniques carried out through face-to-face and direct questions and answers between researchers and resource persons. Along with the development of technology, the interview method can also be done through certain media, such as telephone, email, or skype. Interviews are divided into two categories, namely structured and unstructured interviews.

Observation, data collection technique is done through direct observation. Researchers make observations on the spot on the object of research to be observed using the five senses. Researchers are positioned as observers or outsiders.

Interviews, data collection techniques carried out through face-to-face and direct questions and answers between researchers and resource persons. Along with the development of technology, the interview method can also be done through certain media, such as telephone, email, or skype. Interviews are divided into two categories, namely structured and unstructured interviews

Data reduction, is the stage of qualitative data analysis techniques. Data reduction is simplification, classifying, and removing unnecessary data in such a way that the data can produce meaningful information and make it easier to draw 
conclusions. The large amount of data and the complexity of the data requires data analysis through the reduction stage. This reduction stage is carried out to select whether the data is relevant or not with the final goal

Data display or data presentation is also a stage of qualitative data analysis techniques. Data presentation is an activity when a collection of data is arranged systematically and easily understood, thus providing the possibility of generating conclusions. The form of presentation of qualitativedata can be in the form of narrative text (in the form of field notes), matrices, graphs, networks or charts. Through the presentation of the data, the data will be organized and arranged in a relationship pattern, so that it will be easier to understand.

Conclusion drawing and data verification is the final stage in qualitative data analysis techniques that are carried out to see the results of data reduction still refer to the analysis objectives to be achieved. This stage aims to find the meaning of the data collected by looking for relationships, similarities, or differences to draw conclusions as answers to existing problems.

\section{RESULTS AND DISCUSSION}

\subsection{Elderly Residents in Surabaya}

Table 1. A Elderly Residents in Surabaya

\begin{tabular}{|c|c|c|c|c|}
\hline Year & $\begin{array}{c}\text { Male } \\
(\%)\end{array}$ & $\begin{array}{c}\text { Female } \\
(\%)\end{array}$ & $\begin{array}{c}\text { Population } \\
(\text { people })\end{array}$ & $\begin{array}{c}\text { Percent } \\
(\%)\end{array}$ \\
\hline 2016 & 49,97 & 50,03 & 3.016 .653 & 7,95 \\
\hline 2017 & 49,90 & 50,10 & 3.074 .883 & 8,23 \\
\hline 2018 & 49,82 & 50,18 & 3.094 .732 & 8,53 \\
\hline 2019 & 49,72 & 50,28 & 3.158 .943 & 8,84 \\
\hline 2020 & 49,58 & 50,42 & 2.874 .314 & 9,16 \\
\hline
\end{tabular}

The increasing number of elderly people will have an impact on the dependency ratio of the elderly population. Currently the dependency ratio of the elderly population in the city of Surabaya in 2020 reaches 9.16 . This means that every 100 productive residents of Surabaya City must bear an average of 9 elderly residents [4]

If you look at the demographic structure of the elderly population in the city of Surabaya, the age group that dominates the most is the young elderly group (60-64 years) asmany as 136,985 people, middle elderly (65-69 years) as manyas 94,164 people and the second highest number is the elderly $(70+)$ which is 54,625 inhabitants. This condition shows that the young elderly age group is still the largest, however, if you look at the proportion of elderly people (age 70+) with a not- too-distant difference, it requires attention from various parties. This is mainly related to the health condition of the elderly because as people get older, the percentage of the elderly population who experience health complaints is getting bigger. One indicator of the health condition of the elderly is the morbidity rate. The elderly morbidity rate is the proportion of the elderly population who experience health problems that interfere with daily activities for the past month. BPS data for 2020 recorded the morbidity rate of the elderly population of Surabaya at 9.16 percent. This means that out of every 100 elderly people there are about 9 of them experience pain so that their daily activities are disrupted. If differentiated by gender, the elderly female morbidity rate is slightly lower at 23.85 percent compared to male elderly at 24.38 percent (East Java Elderly Population Profile, 2020).

\subsection{People with Disabilities in Surabaya Children with Disabilities (5-17 Years)}

Table 2. Proportion of Child Disability

\begin{tabular}{|c|c|c|c|c|}
\hline \multirow{2}{*}{$\begin{array}{c}\text { Umur } \\
\text { (tahun) }\end{array}$} & \multirow{2}{*}{$\%$} & \multicolumn{3}{|c|}{ 95\% CI } \\
\cline { 3 - 5 } & & Lower & Upper & $\begin{array}{c}\mathrm{N} \\
\text { Tertimbang }\end{array}$ \\
\hline $5-17$ & 2,86 & 1,82 & 4,47 & 1.413 \\
\hline
\end{tabular}

Adult Disability (18-59 Years)

Table 3. Proportion of Adult Disability

\begin{tabular}{|c|c|c|c|}
\hline & \multicolumn{3}{|c|}{ Tidak Ada Kesulitan } \\
\hline & \multicolumn{2}{|c|}{$\%$} & 81,50 \\
\hline & \multirow{2}{*}{$95 \% \mathrm{CI}$} & Lower & 77,69 \\
\hline & & Upper & 84,79 \\
\hline & \multicolumn{3}{|c|}{ Kesulitan Ringan } \\
\hline & \multicolumn{2}{|c|}{$\%$} & 14,22 \\
\hline & \multirow{2}{*}{$95 \% \mathrm{CI}$} & Lower & 11,66 \\
\hline & & Upper & 17,23 \\
\hline$\ddot{\omega}$ & \multicolumn{3}{|c|}{ Kesulitan Sedang } \\
\hline \multirow{8}{*}{ 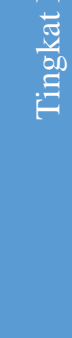 } & \multicolumn{2}{|c|}{$\%$} & 3,75 \\
\hline & \multirow{2}{*}{$95 \% \mathrm{CI}$} & Lower & 2,55 \\
\hline & & Upper & 5,47 \\
\hline & \multicolumn{3}{|c|}{ Kesulitan Berat } \\
\hline & \multicolumn{2}{|c|}{$\%$} & 0,53 \\
\hline & \multirow{2}{*}{$95 \% \mathrm{CI}$} & Lower & 0,25 \\
\hline & & Upper & 1,16 \\
\hline & \multicolumn{2}{|c|}{$\mathrm{N}$ tertimbang } & 4.536 \\
\hline
\end{tabular}

Elderly Disability (>60 Years)

Table 4. Proportion of Elderly Disability

\begin{tabular}{|c|c|c|c|}
\hline \multirow{6}{*}{ 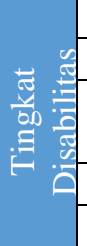 } & \multicolumn{3}{|c|}{ Mandiri } \\
\hline & \multicolumn{2}{|c|}{$\%$} & 74,14 \\
\hline & \multirow{2}{*}{$95 \% \mathrm{CI}$} & Lower & 68,06 \\
\hline & & Upper & 79,41 \\
\hline & \multicolumn{3}{|c|}{ Tergantung Ringan } \\
\hline & \multicolumn{2}{|c|}{$\%$} & 22,56 \\
\hline
\end{tabular}




\begin{tabular}{|c|c|c|}
\hline \multirow{2}{*}{$95 \% \mathrm{CI}$} & Lower & 17,47 \\
\hline & Upper & 28,61 \\
\hline \multicolumn{3}{|c|}{ Tergantung Sedang } \\
\hline \multicolumn{2}{|c|}{$\%$} & 0,47 \\
\hline \multirow{2}{*}{$95 \% \mathrm{CI}$} & Lower & 0,12 \\
\hline & Upper & 1,90 \\
\hline \multicolumn{3}{|c|}{ Tergantung Berat } \\
\hline \multicolumn{2}{|c|}{$\%$} & 1,36 \\
\hline \multirow{2}{*}{$95 \% \mathrm{CI}$} & Lower & 0,45 \\
\hline & Upper & 4,05 \\
\hline \multicolumn{3}{|c|}{ Tergantung Total } \\
\hline \multicolumn{2}{|c|}{$\%$} & 1,46 \\
\hline \multirow[t]{2}{*}{$95 \% \mathrm{CI}$} & Lower & 0,62 \\
\hline & Upper & 3,44 \\
\hline \multicolumn{2}{|c|}{ N Tertimbang } & 658 \\
\hline
\end{tabular}

\subsection{Surabaya City as a Friendly City for Persons with Disabilities and the Elderly}

Meanwhile, the Global Elderly Friendly City Document states that elderly-friendly cities are: (1) elderly-friendly residential areas and houses, (2) public facilities close to elderly residences to encourage active aging, (3) elderly- friendly transportation and infrastructure, (4) age-friendly public parks and entertainment facilities including the elderly,

(5) special discounts for elderly-friendly transportation, food, clothing and boards [6]

In 2013, the city of Surabaya became one of 14 cities in Indonesia that was subjected to a feasibility test as an Elderly Friendly City using 8 indicators set by WHO. This study was conducted by the SurveyMETER Institute in collaboration with the Center for Aging Studies, University of Indonesia funded by the Knowledge Sector, Australian Aid managed by the Asian Foundation. Assessment is carried out using color categories. Based on the color category that is adjusted to the percentage of community assessment scores stating Appropriate and Very Appropriate, the City of Surabaya is narrated as a city that is not yet in accordance with the categoryof Elderly Friendly City.

\subsubsection{Basic Considerations}

Practically, an elderly-friendly city adapts in terms of structure and services so that it can be accessed inclusively for the elderly according to their needs and capacities. The list of WHO guidelines related to elderly-friendly cities includes 8 dimensions, namely: 1) Building and outdoor space; 2) Transportation (transportation); 3) Housing (housing); 4) Social participation (social participation); 5) Respect and social involvement (respect and social inclusion); 6) Civil participation and employment; 7) Communication and information (communication and information); 8) Community support and health services.
Recommended strategy:

Make plans based on information from related SKPDs regarding infrastructure improvement in each measurement dimension. 2. Consolidation and application of laws and regulations that support the application of traffic regulationsand the convenience of the community in obtaining transportation services that pay more attention to the elderlypopulation. 3. Strengthening socialization to stakeholders, community groups and society in general to be able to pay more attention to elderly community groups. 4 . Making rules and outreach to community service facilities or other public facilities to be able to provide special services for theelderly population 5 . Strengthening the image of the elderlypopulation as active, efficient and creative individuals by involving mass media and electronic media. 6 . Incorporating local content regarding the role and explanation of the elderly in the school curriculum to be able to foster a sense of affection and respect for the elderlypopulation from an early age. 7. Conducting research related to capacity building of Elderly Friendly Cities in the community, stakeholders, and government [8]

\subsubsection{Partnership between Local Government and Non-Government Actors}

The success of the program is due to the high commitment of various relevant stakeholders. In terms of old age, several stakeholders who deal directly with the elderly are the City/Regency government, Provincial and Regency/City BKKBN, Health Service, Social Service, andprivate parties or non-governmental organizations. However, the focal point in a district/city area is the regional leader, namely the Mayor or Regent. The Mayor's high alignment and concern for the elderly is reflected in various programs and activities that are fairly active in the Surabaya City area. Of course, the logical consequence of an activity is the sustainable budgeting of regional fund allocations for regional superior programs to improve the welfare of the elderly

Coordination between SKPD (Local Government Work Units) is also one of the keys to the success of a policy and program. Indeed, it is not always easier for cross-SKPD programs and activities to be carried out, especially when speaking within a budgeting framework. Institutional sectoral ego is often an obstacle in a common goal of improving the social welfare of the elderly population. However, if these challenges can be overcome by establishing harmonious and synergistic coordination, then government programs will be more effective and efficient and on target. For this sustainability issue, several SKPDs in the city of Surabaya often synergize in carrying out activities. 


\subsubsection{Pros and Cons of Surabaya as a City of Persons with Disabilities and the Elderly}

Pros and Cons of the City of Surabaya in realizing its ideals as a Friendly City for Persons with Disabilities and the Elderly, of course there are still many things that need to be considered, both in terms of physical infrastructure, implementation of policies and programs as well as related to behavior and public awareness related to meeting the needs of the elderly population and people with disabilities.

\subsubsection{Potential Target Group}

In this study then identify a number of target groups thatcan be the target of the development of the city of Surabayaas a friendly city for people with disabilities and the elderly.

Table 5. Potential Target Group

\begin{tabular}{|c|c|c|}
\hline Target Group & Amount & Condition \\
\hline $\begin{array}{l}\text { Persons with } \\
\text { Disabilities }\end{array}$ & $\begin{array}{l}\text { According to data } \\
\text { from the Surabaya } \\
\text { City Social } \\
\text { Service, in } 2019 \text {, } \\
\text { there were at least } \\
7,112 \text { disabilities }\end{array}$ & $\begin{array}{l}\text { Experiencing } \\
\text { health and social } \\
\text { problems in living } \\
\text { with the community } \\
\text { Public facilities inthe } \\
\text { city of Surabaya } \\
\text { such as sidewalks, } \\
\text { roads, stairs/lifts, } \\
\text { toilets, and modes of } \\
\text { transportation are } \\
\text { not yet friendly for } \\
\text { people with } \\
\text { disabilities }\end{array}$ \\
\hline seniors & $\begin{array}{l}\text { Currently the } \\
\text { dependency ratio } \\
\text { of the elderly } \\
\text { population in the } \\
\text { city of Surabaya } \\
\text { in } 2020 \text { reaches } \\
9.16 \text {. }\end{array}$ & $\begin{array}{l}\text { Many } \\
\text { people } \\
\text { abandoned by their } \\
\text { families in social } \\
\text { institutions and are } \\
\text { often not respected } \\
\text { by the general public } \\
\text { Public facilities inthe } \\
\text { city of Surabaya } \\
\text { such as sidewalks, } \\
\text { roads, stairs/lifts, } \\
\text { toilets, and modes of } \\
\text { transportation are } \\
\text { not yet friendly to } \\
\text { the elderly }\end{array}$ \\
\hline
\end{tabular}

\section{CONCLUSION}

Urban planning and policies that are directed and sustainable are one of the steps in building an elderly-friendly city. All of that begins with understanding the character of the elderly themselves, so that a match is formed between the needs and the character of the elderly population by considering aspects of locality. In line with that, improving thehealth quality of the elderly must remain the main focus. All ofthis can work well if there is a harmonious synergy from all elements of the city, including the local government, relevant stakeholders, and support from all elements of society. The synergy aims to realize the city of Surabaya as a city that is able to accommodate the needs of the disabled and the elderly with all their limitations.

\section{ACKNOWLEDGMENT}

The author wishes to thank the Faculty of Social Science and Law, Universitas Negeri Surabaya, for providing the need to publish this Article

\section{REFERENCES}

[1] A. Purnomosidi, "Konsep Perlindungan Hak konstitusional penyandang disabilitas di Indonesia," Refleksi Hukum: Jurnal Ilmu Hukum, vol. 1, no. 2, pp. 161-174, Apr. 2017.

[2] B. Manan, Perkembangan Pemikiran Dan Pengaturan hak Asasi Manusia di Indonesia. Bandung, West Java: Alumni, 2006.

[3] "Inklusi Penyandang Disabilitas di Indonesia." Jakarta, 2018.

[4] A. Fletcher, Disability Awareness in Action Campaigns Resource Kit No. 3. London, London: Independent Living Institute, 1993.

[5] Sulastio, L. J. Kurniawan, and M. Najih, Paradigma Kebijakan pelayanan publik: Rekonstruksi Pelayanan publik menuju Pelayanan Yang Adil, Berkualitas, demokratis, Dan Berbasis Hak Rakyat. Malang, East Java: Malang Corruption Watch and In-Trans Institute, 2008.

[6] Leksono, "The Influence of Urban Accessibility in Determining Joni Dawud, Siti Widharetno Mursalim, Endah Tri Anomsari, Nur Imam Taufik," J. Adm. Negara, vol. 25, no. 2, pp. 141-159, 2010,

[7] N. K. Reefani, Panduan mendidik anak berkebutuhan khusus. Yogyakarta, Special Region of Yogyakarta: Imperium, 2013.

[8] H. Puspitosari, Khalikussabir, L. J. Kurniawan, and M. Lutfi, Filosofi Pelayanan Publik: Buramnya Wajah Pelayanan Menuju perubahan paradigma pelayanan publik. Malang, East Java: Setara Press, 2016.

[9] M. Syafi'ie, "Pemenuhan Aksesibilitas bagi Penyandang Disabilitas," INKLUSI, vol. 1, no. 2, pp. 269-308, Jul. 2014..

[10] S. I. dan A. Rahmawan, "Klasterisasi Mahasiswa Difabel Indonesia Berdasarkan Background Histories dan Studying Performance," Indones. J. Disabil. Stud., 2014. 